\section{Identifying and Remediating Student Misconceptions in Introductory Biology via Writing-to-Learn Assignments and Peer Review}

\author{
Audrey S. Halim, ${ }^{\dagger}$ Solaire A. Finkenstaedt-Quinn, ${ }^{\dagger}$ Laura J. Olsen, ${ }^{\star}$ \\ Anne Ruggles Gere, ${ }^{\S}$ and Ginger V. Shultz ${ }^{+*}$ \\ ${ }^{\dagger}$ Department of Chemistry, "Department of Molecular, Cellular, and Developmental Biology, and \\ \$Sweetland Center for Writing, University of Michigan, Ann Arbor, MI 48109
}

\begin{abstract}
Student misconceptions are an obstacle in science, technology, engineering, and mathematics courses and unless remediated may continue causing difficulties in learning as students advance in their studies. Writing-to-learn assignments (WTL) are characterized by their ability to promote in-depth conceptual learning by allowing students to explore their understanding of a topic. This study sought to determine whether and what types of misconceptions are elicited by WTL assignments and how the process of peer review and revision leads to remediation or propagation of misconceptions. We examined four WTL assignments in an introductory biology course in which students first wrote about content by applying it to a realistic scenario, then participated in a peer-review process before revising their work. Misconceptions were identified in all four assignments, with the greatest number pertaining to protein structure and function. Additionally, in certain contexts, students used scientific terminology incorrectly. Analysis of the drafts and peer-review comments generated six profiles by which misconceptions were addressed through the peer-review process. The prevalent mode of remediation arose through directed peer-review comments followed by correction during revision. It was also observed that additional misconceptions were elicited as students revised their writing in response to general peer-review suggestions.
\end{abstract}

\section{INTRODUCTION}

Student learning is widely affected by the presence of misconceptions. These misconceptions are tightly held and can be transferred between courses, impacting students long-term and across disciplines (Coll and Treagust, 2003; Yong and Kee, 2017). There are many studies both identifying student misconceptions and investigating how they are formed and ways to remediate them (Duit, 2009; Leonard et al., 2014; Karpudewan et al., 2017a). Student misconceptions must be addressed in a way that does not discredit a student's initial conception, instead reshaping it to promote conceptual change and meaningful learning (Posner et al., 1982; Cakir, 2008). Previous literature has described various ways to correct these misconceptions (Brown, 1992; Abimbola and Baba, 1996; Tekkaya, 2003; Cliff, 2006; Karpudewan et al., 2017b). For example, Abimbola and Baba (1996) identified several misconceptions and alternative conceptions in a biology textbook and encouraged teachers to find the inaccuracies and act as a filter to students, convincing them why the knowledge should be rejected. However, students often come into the classroom with already formed conceptualizations that may not be correct. Therefore, the misconceptions held by students must first be identified before they can be addressed.

Student misconceptions are ubiquitous throughout the science, technology, engineering, and mathematics (STEM) disciplines (Karpudewan et al., 2017a). Because
Nancy Pelaez, Monitoring Editor

Submitted October 3, 2017; Revised January 10 2018; Accepted February 20, 2018

CBE Life Sci Educ June 1, 2018 17:ar28 DOI:10.1187/cbe.17-10-0212

Conflict of interest: WTL assignments described herein were developed by S.A.F.-Q. and L.J.O. *Address correspondence to: Ginger V. Shultz (gshultz@umich.edu).

(c) 2018 A. S. Halim et al. CBE-Life Sciences Education (๑) 2018 The American Society for Cell Biology. This article is distributed by The American Society for Cell Biology under license from the author(s). It is available to the public under an Attribution-Noncommercial-Share Alike 3.0 Unported Creative Commons License (http://creativecommons.org/licenses/ by-nc-sa/3.0).

"ASCB ${ }^{\circledR "}$ and "The American Society for Cell Biology ${ }^{\circledR "}$ are registered trademarks of The American Society for Cell Biology. 
STEM courses tend to build upon one another, the transfer of misconceptions can be especially detrimental to student learning. Introductory biology is an ideal place to identify and remediate misconceptions, as it is a prerequisite for many STEM majors and students pursuing degrees in the health professions. Previous work has identified several areas of student misconceptions in biology, especially at the introductory level (Robic, 2010; Parker et al., 2012). These misconceptions are often identified via interviews, concept inventories, or text analysis (Treagust, 1986; Klymkowsky and Garvin-Doxas, 2008). However, student misconceptions become especially evident in student-generated writing because it provides faculty richer information about students' understanding than do multiple-choice questions or other forced-response assessments (Birenbaum and Tatsuoka, 1987; Parker et al., 2012).

A variety of terms are used when discussing the idea of misconceptions, and there is also a range of meanings that the term "misconception" holds when used in the literature. In this study, we followed the definition provided by the National Research Council (NRC), which states that misconceptions are "understandings or explanations that differ from what is known to be scientifically correct" (NRC, 2012, p. 58). This differs from preconceptions, alternate conceptions, naïve ideas, and commonsense conceptions in that it does not specifically involve student understanding before instruction, provide a neutral stance on student ideas, or regard emergent processes (Clement, 1993; Chi, 2005; Nehm and Ha, 2011; Abraham et al., 2012). In addition to misconceptions, we also examined the incorrect use of scientific terminology, which has been discussed in previous literature (Abimbola, 1988). Throughout the paper, when we discuss misconceptions, we are referring both to misconceptions as defined by the NRC and incorrectly used scientific terminology.

Previous literature has reported misconceptions in several areas of biology. Common misconceptions regarding the topics of protein structure involved protein folding, protein stability, and the effects mutations have on protein structure (Robic, 2010; Shi et al., 2010). Misconceptions regarding photosynthesis have also previously been documented: using diagnostic assessments, researchers studied how students applied their photosynthesis content knowledge to multiple-choice questions or essays, eliciting misconceptions involving the components of photosynthesis and cellular respiration (Haslam and Treagust, 1987; Marmaroti and Galanopoulou, 2006; Shi et al., 2010; Parker et al., 2012). While some sources exist identifying misconceptions about enzymes, such as that they change equilibria of chemical reactions (Shi et al., 2010), these are not as well documented in the literature.

There is literature precedent for identifying student misconceptions via student written responses, which suggests that writing-to-learn (WTL) assignments will serve this function as well (Treagust, 1986; Weston et al., 2015). The initial literature regarding the use of writing for learning in the classroom, including in STEM, derives from the 1980s and showed promise for using writing as a means to better understand how students are thinking about content (Rivard, 1994). WTL is a particular kind of writing broadly defined as a pedagogy, wherein students develop their conceptual understanding of a topic or content area through the process of writing. Analyses of research regarding WTL indicate that it is an effective pedagogy, but its efficacy is dependent on the structure and components of the assignment (Rivard, 1994; Parker et al., 2012; Reynolds et al., 2012; Klein, 2015). Anderson et al. (2015) found that successful writing assignments are interactive, have clear writing expectations, and incorporate meaning-making tasks. Additionally, writing processes that involve cognitive and metacognitive processes lead to learning and can improve student understanding by promoting reflective thinking (Fry and Villagomez, 2012; Klein, 2015). WTL assignments that place students in a role in which they must explain content relative to an authentic context incorporate many of the criteria that enhance learning. WTL may also provide insight into student thinking and conceptions, because it requires students to explicitly articulate content in their own words, which serves as an indicator of their understanding, or misunderstanding, of the content.

This work employs WTL assignments of the sort described above as a mode for both identifying and remediating student misconceptions. The WTL process used here was developed to incorporate the criteria detailed above to enhance student learning. In these assignments, students engage in a process in which they first respond to a given audience about a scenario, then participate in student-mediated peer review, and finally revise their writing based on the feedback they received and how their knowledge of the content has developed (Shultz and Gere, 2015; Finkenstaedt-Quinn et al., 2017). In particular, the peer-review and revision components of these assignments provide space for students to correct their mistakes (Zhang et al., 2017). The objective of this work is to identify misconceptions in student writing and peer-review comments in order to investigate the role of the writing process in reshaping student ideas and remediating misconceptions. This study was framed by the following research questions:

1. What misconceptions do concept-directed writing assignments expose in introductory biology courses?

2. How are these misconceptions addressed through the process of peer review and revision entirely mediated by students?

\section{THEORETICAL FRAMEWORK}

This study uses a social constructivist theoretical framework, whereby students are actively constructing and adapting their knowledge in both social and personal terms through the process of writing and peer review (Ferguson, 2007). Each student must first draw from previous experiences with content in order to respond to the various writing prompts (Ferguson, 2007). They can then build on that knowledge during revision, either by re-examining their own knowledge or through the lens of their peers. Additionally, as Vygotsky theorized, writing facilitates inner speech through its ability to capture thoughts using language (Vygotsky, 1962). The social interactions guiding student learning are captured by the WTL assignments in two ways: 1) when writing about a scenario, students address a specific audience with less advanced content knowledge than themselves; and 2) during each writing assignment, students interact with a few peers through a peer-review process. The WTL assignments presented herein combine the acts of articulating knowledge in authentic contexts with engaging in a social knowledge-building process to identify and address areas of poor understanding. 
From a constructivist perspective, knowledge is built by remodeling pre-existing knowledge to incorporate or be superseded by new knowledge (Bodner, 1986; Hendry, 1996). Students engage with and present concepts differently depending on the application to which they need to apply those concepts or the context in which they are using those concepts (Duit and Treagust, 2003). Both of these points indicate that the context in which knowledge construction occurs is important. Thus, by situating assignments in authentic contexts, one can more accurately assess student understanding.

Peer review provides an opportunity for students to learn from one another both when reading their peer's work before giving feedback and when receiving feedback (Lundstrom and Baker, 2009) and is known to enhance learning (Timmerman, 2008; Patchan et al., 2009; Cho and MacArthur, 2010; Russell, 2013; Klein, 2015; Zhang et al., 2017). When peer review is guided by a detailed rubric, as it was in this study, students provide substantive feedback that can lead to revision (Patchan et al., 2009; Zhang et al., 2017), thereby supporting knowledge construction through social interaction. Feedback from multiple peers additionally results in greater writing improvement than when a student receives feedback from only the instructor (Patchan et al., 2009; Cho and MacArthur, 2010). Incorporating feedback from multiple peers provides more opportunities for students to learn through social interaction, either by identifying their own misconceptions or having the misconceptions identified for them, in a way that may not occur in more instructor-oriented practices (Pelaez, 2003). Revision then provides an opportunity for students to correct any identified misconceptions.

\section{METHODS}

This study involved the analysis of qualitative data consisting of student-generated responses to four writing assignments and the corresponding peer feedback. Analysis of these data provided the research team with insight into the misconceptions present in students' responses and the types of peer interactions that occurred during the WTL process. These data were quantitatively transformed to investigate the prevalence of certain misconceptions and to analyze the changes between initial and revised drafts of each assignment and the relationship of these changes to peer review.

\section{Setting and Participants}

This study took place at a large, midwestern university in an introductory-level cell and molecular biology course intended for first-year students. The course was taught by two professors. There were 36 students in the course. Demographics were collected from 35 of the 36 students using a precourse survey: of the 35 students who completed the survey, 17 were female, four were first-generation college students, and five were non-U.S. born. There were seven Asian, three Black American, and two Latino/a students. The majority of students indicated a major other than biology and had little experience with writing and peer review. The course consisted of in-class activities, semiweekly quizzes, and four WTL assignments. One of the four assignments was offered for extra credit, with 29 of the 36 students completing the assignment.

\section{WTL Assignments}

The four WTL exercises were assigned throughout the term and focused on protein structure, photosynthesis, recombinant DNA, and enzymes to support student learning of important and/or difficult concepts discussed in class (see WTL prompts in the Supplemental Material). Each assignment included clear learning outcomes presented in the prompt that were reflected in the rubrics guiding peer review and revision (see WTL prompts in the Supplemental Material). The assignments were developed by a team consisting of the primary course instructor (L.J.O.), the researcher (S.A.F.Q.), and two instructors from the campus writing center. For each WTL assignment, students wrote an initial draft in response to a prompt, participated in student-mediated anonymous peer review, and revised their original responses. Students gave peer-review comments to and received peer-review feedback from an average of three classmates (ranging from one to five classmates) for each of the assignments. The purpose of using peer review as part of the WTL assignments is twofold: 1) peer review supports additional student learning from their peers, and 2) it mitigates the need for instructors to evaluate student written work. Two peer writing tutors, students who had previously taken the course, were available to assist students with peer review or revision and to answer questions regarding the writing assignments and content involved. Credit was assigned based on effort and completion of the assignment; students could lose points for minimal effort or a large number of errors. Assigning credit based on effort and completion, as opposed to content, further removes the need for instructors to provide detailed feedback to students and reduced the time spent on grading. Each assignment was comparable in magnitude to course homework.

\section{Data Collection and Analysis}

The research team obtained institutional review board approval (HUM00115139) to collect and use student information and responses. Of the 36 students in the course, 35 gave consent to use their writing. Of those, 30 completed all steps of the WTL process for the protein structure assignment, 27 for the photosynthesis assignment, 26 for the enzymes assignment, and 29 for the recombinant DNA assignment (see Supplemental Table S1 for the number of students who completed each aspect of the assignments).

Initial and revised student responses to each writing assignment were collected in a single document using Track Changes in Microsoft Word and analyzed for existing and altered or added misconceptions to ensure that all modifications were visible between both drafts. Upon preliminary analysis of the four assignments, the research team noticed that many misconceptions were present in the student writing. Misconceptions were first identified by two members of the research team and discussed with two content experts. Once identified in both initial and revised drafts, the misconceptions were categorized into themes that were then refined by consultation with the primary course instructor. The initial and revised responses were then analyzed independently for the presence or absence of misconceptions, and each was given a score based on the number of misconceptions present. These misconceptions were identified as incorrect terminology, prompt-specific content, and misconceptions pertaining to general biology concepts. The prompt-specific 


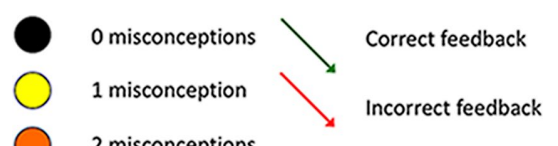

2 misconceptions

3 misconceptions

4 misconceptions

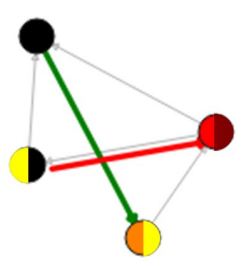

FIGURE 1. Example of a sociogram. Each circle represents a student, with the color indicating the number of misconceptions contained in the initial (left half) and revised (right half) drafts. The arrows represent peer reviews, with directionality indicated by the arrowhead; green arrows indicate correct feedback, and red arrows indicate incorrect feedback. Peer reviews not pertaining to misconceptions are indicated in gray.

content refers to misconceptions that are in fact misconceptions, but relate more to the assignment background information than the main learning outcomes for the assignment (see Tables 2 and 3 later in this article). After analysis of the writing, the peer feedback was analyzed by the same two members of the research team to identify whether peers commented on these same misconceptions in the papers they read.

Sociograms were generated to visualize how the peer interactions influenced changes in student misconceptions (Scott, 1991; Kadushin, 2012; Grunspan et al., 2014). Each student, represented as a circle (or node) in Figures 1 and 2, received a score based on the number of misconceptions present in their drafts. Each circle is divided into halves, with the initial misconception score shown on the left and the revised misconception score on the right. The number of misconceptions is indicated by color, where zero is black, one is yellow, two is orange, three is red, and four is maroon. In two situations, a student corrected an initial misconception then added another misconception, showing a net change of zero in the sociogram, although remediation and addition occurred as a result of peer review. These were denoted with asterisks in the relevant sociogram (Supplemental Figure S1). The arrows (or edges) indicate the peer reviews given and are colored if misconceptions were addressed: red arrows show a peer review directly providing incorrect information, while green arrows show direct correct conceptual statements from peer review. Gray arrows indicate peer feedback that did not involve a misconception. Responses from students who did not participate in all three steps of the WTL assignment were not used when diagramming the social networks that occurred.

Examination of the sociograms for each of the four assignments led to the development of six profiles describing what roles peer review and revision played in the student writing containing misconceptions. The profiles were developed by examining unique cases of interactions between peers and generating a qualitative description for each. Following this, we determined the number of instances of each case among the four assignments.

\section{RESULTS}

\section{Identification of Student Misconceptions}

Student writing products were analyzed across the four WTL assignments covering the topics of protein structure, photosynthesis, recombinant DNA, and enzymes. Misconceptions were identified in both drafts of each of the assignments. Tables 1-4 show the identified misconceptions organized by assignment and theme as well as student examples of each misconception. The number of times each misconception was found in the initial and final drafts is also noted. In some situations, student writers produced the same misconception, leading the research team to analyze the misconceptions in two ways for each assignment: 1) considering the number of students who included the misconceptions in their writing and 2) considering the number of unique concepts around which students exhibited misconceptions. While there is some overlap between the newly identified and previously recorded misconceptions (e.g., a misunderstanding of how ATP is formed in plants; Parker et al., 2012), we identified a number of misconceptions not currently present in the literature. For each assignment, we additionally categorized the misconceptions into multiple themes dependent on the content that challenged students. A recurrent theme between assignments was the incorrect use of terminology, and two of the assignments showed misconceptions specific to the scenario of the assignment's prompt.

Of the four assignments, the protein structure written responses contained the 
TABLE 1. Misconceptions identified in the protein structure assignment ${ }^{a}$

\begin{tabular}{|c|c|c|c|c|}
\hline Theme & Misconception & Student example & No. initial & No. final \\
\hline \multirow[t]{3}{*}{$\begin{array}{l}\text { Prion effect on folding/ } \\
\text { protein structure }\end{array}$} & $\begin{array}{l}\text { Prion disease causes a mutation in primary } \\
\text { structure and this is the cause of protein } \\
\text { misfolding. }\end{array}$ & $\begin{array}{l}\text { "The number of alpha helices and beta sheets in } \\
\text { the protein's secondary structure are changed } \\
\text { in diseased proteins [as] the result of changes } \\
\text { in a protein's amino acid structure." }\end{array}$ & 4 & 4 \\
\hline & $\begin{array}{l}\text { 1) Prion disease is a virus; 2) viruses cause } \\
\text { protein misfolding. }\end{array}$ & $\begin{array}{l}\text { "Secondary structure of the protein changes due to } \\
\text { a virus." }\end{array}$ & 1 & 1 \\
\hline & $\begin{array}{l}\text { 1) Prion disease causes mutations; } \\
\text { 2) mutations can occur at the secondary } \\
\text { level. }\end{array}$ & $\begin{array}{l}\text { "The sequence of the amino acid chain remains } \\
\text { the same, but the secondary structure of the } \\
\text { protein changes due to a virus." }\end{array}$ & 1 & 1 \\
\hline \multirow{7}{*}{$\begin{array}{l}\text { Inherent characteristics } \\
\text { of protein structure/ } \\
\text { levels }\end{array}$} & $\begin{array}{l}\text { Changes in one protein will impact the } \\
\text { entire cellular function. }\end{array}$ & $\begin{array}{l}\text { "This [prion disease] also changes the quaternary } \\
\text { structure and the function of the cell." }\end{array}$ & 0 & 1 \\
\hline & $\begin{array}{l}\text { Levels other than quaternary structure } \\
\text { involve multiple polypeptide chains. }\end{array}$ & $\begin{array}{l}\text { "Polypeptide chains can hydrogen bond to other } \\
\text { polypeptide chains, forming the protein's } \\
\text { secondary structure." }\end{array}$ & 2 & 1 \\
\hline & $\begin{array}{l}\text { Quaternary structure occurs between } \\
\text { multiple proteins. }\end{array}$ & $\begin{array}{l}\text { "The quaternary structure of a protein refers to the } \\
\text { interactions between two or more proteins." }\end{array}$ & 6 & 9 \\
\hline & $\begin{array}{l}\text { Misfolding in the secondary structure does } \\
\text { not impact higher levels of protein } \\
\text { structure. }\end{array}$ & $\begin{array}{l}\text { "A change in the secondary structure does not } \\
\text { affect any of the other levels of a protein." }\end{array}$ & 4 & 1 \\
\hline & $\begin{array}{l}\text { Proteins unfold as part of the tertiary } \\
\text { structure. }\end{array}$ & $\begin{array}{l}\text { "Protein folding and unfolding occurs at tertiary } \\
\text { level." }\end{array}$ & 1 & 1 \\
\hline & $\begin{array}{l}\text { A change at one level affects all other levels } \\
\text { of protein structure. }\end{array}$ & $\begin{array}{l}\text { "This change in primary structure ... can involve } \\
\text { all levels of proteins because amino acids in } \\
\text { beta sheets are able to form hydrogen bonds } \\
\text { with another peptide chains." }\end{array}$ & 1 & 0 \\
\hline & Tertiary structure disregarded. & $\begin{array}{l}\text { "The quaternary structure is a combination of } \\
\text { different secondary structures." }\end{array}$ & 1 & 0 \\
\hline & $\begin{array}{l}\text { Protein "unfolding," "misfolding" and } \\
\text { "denaturing" are the same. }\end{array}$ & $\begin{array}{l}\text { "The unfolding or denaturing of proteins can be } \\
\text { caused by many different things including } \\
\text { disease and high temperatures." }\end{array}$ & 1 & 1 \\
\hline & "Alpha helix" is the same as "double helix." & $\begin{array}{l}\text { "Secondary structures form double helices and } \\
\text { beta sheets." }\end{array}$ & 1 & 1 \\
\hline
\end{tabular}

${ }^{\mathrm{a} A}$ total of 21 content-specific misconceptions were identified, with 35 total occurrences among drafts submitted by 30 students. Student examples in quotes were drawn directly from student writing. The numbers of each misconception in the initial and final drafts are noted.

greatest number of misconceptions, with 15 different misconceptions identified for 33 total occurrences among students (Table 1). We categorized these misconceptions into the themes of prion effect on protein folding and structure and the inherent characteristics of the levels of protein structure. In addition, there were three distinct instances in which students used terminology incorrectly. The largest number of misconceptions fell within the inherent characteristics of the levels of protein structure theme, with nine different misconceptions. Students demonstrated misconceptions for each of the levels of protein structure. Of the 22 students who incorrectly wrote about the levels of protein structure, 11 of them, or approximately onethird of all students, indicated that quaternary structure is between multiple proteins instead of multiple polypeptide subunits. Students' writing indicated that they also had difficulty identifying the levels at which prion disease would impact protein structure and how those impacts would manifest, with seven identified misconceptions among 10 students. Many of these involved students misattributing prion disease to a mutation and incorrectly describing how a mutation could impact protein folding.

We identified the second greatest number of student misconceptions in the photosynthesis assignment (Table 2). There were 12 different misconceptions: only three of those were found to be shared between two different students. These were divided into the themes of energy and cycle components. 
TABLE 2. Misconceptions identified in the photosynthesis assignment ${ }^{a}$

\begin{tabular}{|c|c|c|c|c|}
\hline Theme & Misconception & Student example & No. initial & No. final \\
\hline \multirow[t]{4}{*}{ Energy } & $\begin{array}{l}\text { Energy is formed rather than stored in ATP and } \\
\text { NADPH. }\end{array}$ & "Energy formed is called ATP and NADH." & 0 & 1 \\
\hline & $\begin{array}{l}\text { Glucose itself stores energy-not that energy is } \\
\text { released during the process of glucose } \\
\text { breakdown. }\end{array}$ & $\begin{array}{l}\text { "Cellular respiration breaks down glucose to } \\
\text { make energy and support growth in plants." }\end{array}$ & 1 & 0 \\
\hline & $\begin{array}{l}\text { Light excitation moves the entire molecule/ } \\
\text { protein/structure to a higher energy level, } \\
\text { not just the excited electron. }\end{array}$ & $\begin{array}{l}\text { "The excitement of pigments ... raises pigments } \\
\text { to higher energy level." }\end{array}$ & 2 & 2 \\
\hline & Electrons move freely. & $\begin{array}{l}\text { "The electron travels from one chlorophyll to } \\
\text { another." }\end{array}$ & 2 & 1 \\
\hline \multirow[t]{5}{*}{ Cycle components } & The entire cell participates in respiration. & $\begin{array}{l}\text { "[During respiration] the cell will begin the TCA } \\
\text { cycle and produce ATP." }\end{array}$ & 1 & 0 \\
\hline & The Calvin cycle produces ATP. & $\begin{array}{l}\text { "This cycle [the Calvin cycle] requires ATP, } \\
\text { NADPH, and carbon dioxide to produce } \\
\text { glucose and ATP." }\end{array}$ & 1 & 1 \\
\hline & Sugar is an input of the Calvin cycle. & $\begin{array}{l}\text { "CO fixation is coupled with a sugar to create } \\
\text { glucose." }\end{array}$ & 1 & 0 \\
\hline & Oxygen is a by-product of respiration. & "The by-product of this [respiration] is oxygen." & 1 & 0 \\
\hline & $\begin{array}{l}\text { NADPH oxidizes water in order to remove } \\
\text { electrons. }\end{array}$ & $\begin{array}{l}\text { "NADPH present here [in PSII] oxidizes water } \\
\text { molecules in order to remove electrons." }\end{array}$ & 1 & 1 \\
\hline Prompt specific & C3 plants rely on the Calvin cycle for energy. & $\begin{array}{l}\text { "C3 plants are more digestible and are used } \\
\text { primarily in the Calvin cycle." }\end{array}$ & 1 & 1 \\
\hline \multicolumn{5}{|c|}{ Incorrect use of terminology } \\
\hline & ATP is an enzyme. & $\begin{array}{l}\text { "These macromolecules are the main energy } \\
\text { supply of plants, as they produce adenosine } \\
\text { triphosphate (ATP), an enzyme that is able to } \\
\text { provide energy where it is needed." }\end{array}$ & 1 & 0 \\
\hline & Chloroplast and chlorophyll are the same. & "Sunlight energizes a pigment called chloroplast." & 1 & 3 \\
\hline
\end{tabular}

${ }^{a}$ A total of 16 content-specific misconceptions were identified, with 17 total occurrences between drafts submitted by 27 students. Student examples in quotes were drawn directly from student writing. An example of a prompt-specific misconception can be seen here. The numbers of each misconception in the initial and final drafts are noted.

Additionally, there were cases of incorrectly used terminology and a prompt-specific misconception. Seven students demonstrated misconceptions related to the topic of energy, while eight students had misconceptions related to cycle components. Throughout the two themes and incorrect use of terminology, five misconceptions were related to the terms "chlorophyll" or "chloroplast," and two involved the process of respiration.

Across the four assignments, the fewest number of misconceptions were observed in student writing about enzymes, with eight misconceptions present among 14 students (Table 3 ). These were categorized into two themes: process of inhibition and enzyme function. There were also misconception themes related to incorrect use of terminology and promptspecific misconceptions that related directly to the scenario presented in the assignment. A total of four misconceptions fell into the theme of process of inhibition, and all involved irreversible and reversible inhibition, with half of the students writing that competitive inhibition is always reversible and noncompetitive inhibition is always irreversible. Six students demonstrated a misconception of enzyme functions, conveying in their writing that enzymes can act directly as inhibitors. While enzymes in some cases can affect a downstream process, the research team discussed with the course instructor that this was beyond the scope of what was taught in the introductory-level class. One student stated that most enzymes are proteins, and while the research team acknowledges that this is accurate, because there are only a few known ribozymes, this was beyond the scope of what was taught in the introductory-level class. A number of misconceptions appeared in the revised drafts of this assignment. This may be attributed to the fact that students initially did not completely address this aspect of the writing assignment and, in response to peer review, wrote additional details that brought additional misconceptions to the surface in the revised response. It is important to note that, in these situations, none of the students explained the content to their peers. They simply asked for clarification and further details, which resulted in the peers adding misconceptions in their revised draft. The frequency of this feedback is noted in Table 5 .

In the recombinant DNA assignment, 11 students included four different misconceptions in their initial drafts (Table 4). These misconceptions fell into two themes, process of recombination and plasmid relation to cell survival, with almost half the students struggling with the process of recombination. Within the process of recombination, four students misunderstood the concept of transformation and believed that PCR should be performed after transformation to identify whether transformation had occurred. Additionally, 
TABLE 3. Misconceptions identified in the enzymes assignment ${ }^{a}$

\begin{tabular}{|c|c|c|c|c|}
\hline Theme & Misconception & Student example & No. initial & No. final \\
\hline \multirow[t]{4}{*}{$\begin{array}{l}\text { Process of } \\
\quad \text { inhibition }\end{array}$} & $\begin{array}{l}\text { Irreversible inhibition is related } \\
\text { to noncovalent binding. }\end{array}$ & $\begin{array}{l}\text { "Some inhibitors cause irreversible inhibition where inhibitors } \\
\text { interact with enzymes noncovalently." }\end{array}$ & 0 & 1 \\
\hline & $\begin{array}{l}\text { A reversible inhibitor only binds } \\
\text { to the active site. }\end{array}$ & $\begin{array}{l}\text { "During reversible inhibition, some inhibitor molecule } \\
\text { noncovalently bonds to the active site of the enzyme } \\
\text { blocking the actual substrates to bind to the site." }\end{array}$ & 0 & 1 \\
\hline & $\begin{array}{l}\text { Competitive inhibition is always } \\
\text { reversible, while noncom- } \\
\text { petitive is always irrevers- } \\
\text { ible. }\end{array}$ & $\begin{array}{l}\text { "Noncompetitive inhibitors are irreversible, meaning that once } \\
\text { the inhibitor binds covalently to the allosteric site and } \\
\text { makes modifications to the structure, and it cannot be } \\
\text { undone." }\end{array}$ & 1 & 3 \\
\hline & $\begin{array}{l}\text { An irreversible inhibitor only } \\
\text { binds to the allosteric site. }\end{array}$ & $\begin{array}{l}\text { "During irreversible inhibition, however, the inhibitor binds to } \\
\text { the allosteric site and changes the shape of the active site } \\
\text { that the substrate is supposed to bind." }\end{array}$ & 0 & 1 \\
\hline Enzyme function & Enzymes act as inhibitors. & $\begin{array}{l}\text { "An enzyme can inhibit a reaction competitively and non } \\
\text { competitively." }\end{array}$ & 3 & 6 \\
\hline \multirow[t]{4}{*}{ Prompt specific } & $\begin{array}{l}\text { Misunderstanding of protein } \\
\text { structure exhibited. }\end{array}$ & $\begin{array}{l}\text { "The most effective way to target telomerase would be } \\
\text { targeting the quaternary structure." }\end{array}$ & 1 & 1 \\
\hline & $\begin{array}{l}\text { Telomerase is permanently } \\
\text { active in somatic cells. }\end{array}$ & $\begin{array}{l}\text { "In somatic cells, or cancerous cells, telomerase is usually } \\
\text { found in a permanently activated state." }\end{array}$ & 0 & 1 \\
\hline & \multicolumn{4}{|c|}{ Incorrect use of terminology } \\
\hline & Most enzymes are proteins. & $\begin{array}{l}\text { "Most enzymes are proteins, and their specificity comes from } \\
\text { their unique three-dimensional structures." }\end{array}$ & 1 & 0 \\
\hline
\end{tabular}

there were five cases in which the terminology was used incorrectly. A total of five misconceptions touched on vectors or plasmids. Three of these misconceptions across five students involved misuse of the terms "template DNA," "plasmid," and "vector."

An emergent theme throughout the assignments was incorrect use of terminology. Incorrect usage took two forms: 1) an incorrect use of the term and 2) conflation of terms. We identified two potential modes by which terms were conflated. In some cases, students associated terms that played roles in the same process, such as "ATP" and "enzyme" in the photosynthesis assignment, whereas in other cases, students did not distinguish between closely related terms that had slightly different conceptual meaning, such as "misfolding," "unfolding," and "denaturation" in the protein prompt.

\section{Impacts of Peer Review on Student Misconceptions}

The goal of the second stage of the analysis was to determine whether students remediated or added misconceptions through the peer-review process. We identified changes in the number of misconceptions between drafts and determined whether students received peer reviews addressing the misconception(s) contained in their writing, noting whether the peer reviews provided correct or incorrect content feedback. Across all four writing assignments, there were a total of 58 misconceptions in the initial drafts and 59 in the revised drafts. Of these, 16 misconceptions in the initial draft were remediated, while 17 misconceptions were elicited through the revision process. Only three of 17 misconceptions that were added could be traced directly to peer feedback, with the peer-review comment specifically providing incorrect information. While

TABLE 4. Misconceptions identified in the recombinant DNA assignment ${ }^{\mathrm{a}}$

\begin{tabular}{|c|c|c|c|c|}
\hline Theme & Misconception & Student example & No. initial & No. final \\
\hline \multirow[t]{2}{*}{ Understanding of process } & Role of the plasmid was misunderstood. & $\begin{array}{l}\text { "The important DNA sequences from } \\
\text { plasmids can be cloned." }\end{array}$ & 1 & 3 \\
\hline & $\begin{array}{l}\text { Role of antibiotic resistance gene in } \\
\text { identification of successfully trans- } \\
\text { formed bacteria was misunderstood. }\end{array}$ & PCR takes place after transformation. & 4 & 3 \\
\hline $\begin{array}{l}\text { Plasmid relation to cell } \\
\text { survival }\end{array}$ & $\begin{array}{l}\text { Bacteria selectively uptake plasmids } \\
\text { containing the ampicillin resistance } \\
\text { gene. }\end{array}$ & $\begin{array}{l}\text { "Uptake will only occur if the cell's chance } \\
\text { of survival is heightened with plasmid } \\
\text { retention." }\end{array}$ & 2 & 2 \\
\hline \multicolumn{5}{|c|}{ Incorrect use of terminology } \\
\hline & $\begin{array}{l}\text { Definitions of "vector," "plasmid," and } \\
\text { "template DNA" were misunderstood. }\end{array}$ & $\begin{array}{l}\text { "A vector plasmid is a circular chromosome } \\
\text { which will ultimately hold three vital } \\
\text { genes." }\end{array}$ & 5 & 3 \\
\hline
\end{tabular}

${ }^{\mathrm{a} A}$ total of nine content-specific misconceptions were identified, with 14 total occurrences between drafts submitted by 29 students. Student examples in quotes were drawn directly from student writing. The numbers of each misconception in the initial and final drafts are noted. 
TABLE 5. Number of misconceptions and the effects of peer review

\begin{tabular}{|c|c|c|c|c|c|c|}
\hline & & & Number of mi & conceptions & & \\
\hline & $\begin{array}{c}\text { Total in } \\
\text { initial draft }\end{array}$ & Remediated & $\begin{array}{c}\text { Elicited through } \\
\text { peer review }^{\mathrm{b}}\end{array}$ & $\begin{array}{c}\text { Elicited due to } \\
\text { incorrect peer } \\
\text { feedback }\end{array}$ & $\begin{array}{c}\text { Elicited due to additional } \\
\text { information requested by } \\
\text { peer reviewer }\end{array}$ & $\begin{array}{c}\text { Success rate (percent of } \\
\text { misconceptions corrected } \\
\text { after revision) }\end{array}$ \\
\hline $\begin{array}{l}\text { Protein structure } \\
\qquad(N=30)\end{array}$ & 27 & 7 & 4 & 2 & 1 & 25.9 \\
\hline $\begin{array}{l}\text { Photosynthesis } \\
\qquad(N=27)\end{array}$ & 13 & 5 & 3 & 1 & 1 & 38.5 \\
\hline Enzymes $(N=26)$ & 6 & 1 & 9 & 0 & 5 & 16.7 \\
\hline $\begin{array}{l}\text { Recombinant } \\
\text { DNA }(N=29)\end{array}$ & 12 & 3 & 2 & 0 & 2 & 25 \\
\hline
\end{tabular}

six misconceptions were due to students adding misconceptions unprompted during their revision process, the other eight were included when peers noted that the writer should include additional information to address the assignment but did not specifically introduce a misconception. Overall, 27 peer reviews played a role in the social interactions surrounding student misconceptions: 24 directly provided correct feedback through peer review and led to remediation of a misconception, while three directly gave incorrect feedback and led to an addition of a misconception (Supplemental Table S2). In addition to the role of feedback from peer review in the process of remediation and additions of misconceptions in student work, we posit that reading a peer's paper also plays a role. The presence of this effect can be characterized indirectly by examining the appearance and disappearance of misconceptions not related to peer review and by viewing the papers each student read.

To both visualize the role of peer review and gain insight into how reading peers' writing impacts student misconceptions, the research team generated sociograms to illustrate students' revisions and the interactions through peer review (Figure 2 and Supplemental Tables S1 and S2). Each student is represented by a circle in the figure, and each half is colored according to the number of misconceptions present in their drafts, with the initial draft indicated on the left side and the revised draft on the right. The arrows indicate the peer reviews given and whether misconceptions were directly addressed. Visualizing student interactions in this way allowed us to develop six interesting cases of peer interactions. To present these cases, this paper will focus on the results shown in the visual depicting the photosynthesis assignment (Figure 2). This particular assignment was chosen because it contained a moderate number of misconceptions and several types of peer interactions, with five of our six cases present (the sixth case, F, can be found in Supplemental Figure S1). Social network visuals for the other three prompts can be found in the Supplemental Material.

Incorrect Feedback. In case A, a student whose work did not contain any misconceptions provided incorrect feedback to a peer that resulted in the introduction of a misconception. Student A's peer-review comment discussed the components of photosynthesis, which were correctly mentioned in the other student's initial draft of the assignment. However, Student A's comment incorrectly suggested changing chlorophyll to chloroplast, which led the peer to add a misconception during revision. This case occurred only three times across the four assignments.

Correct Feedback Despite Own, Unrelated, Misconception. The second case, B, occurred when a student corrected a peer's misconception despite demonstrating a misconception in his/ her own initial draft. Student B initially had one misconception, which was retained, yet corrected another student's misconception. The misconception held by Student B, which regarded photosynthesis occurring in the chlorophyll of plant cells, was unrelated to the misconception that the student was able to address, in which a peer incorrectly identified ATP as an enzyme. Although the misconceptions differed, Student B demonstrated the ability to provide accurate feedback on content despite having flawed knowledge of a different component of the material. This case occurred nine times throughout all four assignments.

Fixed Own Misconception. In case C, a student was able to both provide correct feedback to a peer and fix his/her own misconception, but did not receive specific feedback from another peer directing the student to fix it. This student had two misconceptions in the initial response pertaining to the theme of energy. In peer review, the student was able to address the peer's misconception about the components of respiration. Additionally, while Student C did not receive direct feedback to address either of his/her own misconceptions, the student still corrected one of two initial misconceptions. Of the drafts that this student read, all three presented the information correctly for the misconception that the student fixed, suggesting that reading and critically evaluating others' writing may be beneficial. Interestingly, two of the three papers Student $C$ read contained one misconception, one similarly related to energy and the other involving the components of respiration, but the student did not incorporate these into the revised draft. This case of fixing a misconception without direct feedback was unique and occurred only once across the assignments. 
Remediated a Misconception. Case D is represented by a student who was able to correct one of a peer's misconceptions and did not have any misconceptions in his/her own writing. This case is interesting, in that Student D's initial draft correctly discussed the material pertaining to a peer's two misconceptions, yet the student was able to identify only one of the misconceptions in a peer's work. There were two instances when peers only commented on one of the misconceptions in the papers they read, despite the presence of a second. There were seven instances in which the single misconception in a paper was identified and correct feedback provided, leading to remediation.

Added Misconceptions. Overall, there were eight instances in which students added misconceptions without receiving incorrect peer reviews, as exemplified by case E. Student E's initial misconception was about energy, and the revised response contained an additional misconception regarding energy and one about the components of photosynthesis. None of the papers this student read contained either of the misconceptions; however, two peers did suggest that the student writer should include more detail, which may have resulted in the emergence of the new misconception. There were also instances in which misconceptions arose during revision without students being prompted to add more detail to the specific content.

Feedback Provided but Ignored. Case F represents instances in which students ignored feedback and misconceptions that their peers had identified. There were no instances of this in the photosynthesis assignment, but there were seven cases throughout the other three assignments, mostly in the protein structure assignment (see Supplemental Figures S1-S3 for examples). In all drafts, other revisions were made, so the student writers may not have incorporated the information because they believed their original conception was still correct and chose to ignore the feedback. For example, Student F's initial draft stated incorrectly that prion disease causes a mutation at the primary level of another protein, leading to that protein misfolding. Although one student directly mentioned that the original paper had incorrect information, and Student F made significant changes in the revised response, the student did not incorporate a correction.

\section{DISCUSSION}

We examined four WTL assignments implemented in an introductory biology course for the presence of misconceptions and to characterize the nature of the peer interactions that occurred during the peer review. Overall, it is evident that the WTL assignments elicited student misconceptions across common topics such as protein structure, photosynthesis, enzymes, and recombinant DNA. Our newly identified misconceptions differ from those previously reported in literature. The majority of the misconceptions related to protein structure were tied to levels of protein structure and the interactions between levels and their functions, which varies from previous literature that indicated that students did not have difficulty understanding the levels of protein structures (Robic, 2010). While prior literature reported misconceptions regarding the randomization of mutations and their effects on protein structure in general (Smith et al., 2008), our newly identified misconceptions involved the origins of mutations, effects that mutations may have on specific levels of proteins, and how that impacts protein function. Previous studies have also found that misconceptions exist regarding the interior elements of a protein's alpha helix (Loertscher et al., 2014). The misconceptions that we identified relate more to the basic understanding of protein secondary structure and conflating alpha and double helices. Student writing in response to the photosynthesis prompt contained a range of misconceptions, with two students demonstrating the same misconception once, but the majority involved components of the various cycles making up respiration, such as the Calvin cycle. These misconceptions involved the process of photosynthesis and cellular respiration, but differ from previous findings in that they focused on the energy involved as well (Parker et al., 2012). The enzyme and recombinant DNA assignments had the fewest number of misconceptions. We did not find support of previous literature reporting the misconception that enzymes act on the equilibria of chemical reactions (Shi et al., 2010). Instead, students struggled the most with enzyme function and inhibition, the process of recombination, and terminology. In general, a number of student misconceptions appear to be related to incorrect memorization of information. Some of these errors indicate that students are not thinking about a piece of knowledge in context with related content, which might otherwise have made the error apparent to them.

In particular, students showed the most difficulty with the terminology used in the recombinant DNA assignment. This is perhaps due to the terminology-rich context and demonstrates that WTL may be particularly helpful in identifying specific terms that students are struggling to understand or conflating with other terms (Abimbola, 1988). Importantly, our analysis of the four writing assignments revealed misconceptions that had not been previously documented in the literature. Thus, peer review embedded in WTL processes has potential as a tool to elicit student's misconceptions, which may remain unidentified when traditional assignments or assessment methods are used (Pelaez, 2003). Further analysis, possibly via interviews, may provide information on how these processes function to draw out misconceptions.

Analysis of the peer-review and revision process showed that students both added and remediated misconceptions in the WTL assignments presented herein. There was a small increase in the number of misconceptions between drafts, going from 58 to 59 , but the increase was due to new misconceptions being elicited through general peer comments rather than explicit suggestions to add incorrect information. Of the original misconceptions, 16 were remediated though 24 peer reviews that identified misconceptions. The difference in number between peer-review comments and remediated misconceptions originates from two circumstances: multiple students are providing feedback about the same misconception and not all feedback identifying misconceptions was accepted by the writers. The latter instance is demonstrated in case $\mathrm{F}$ of the peer-review profiles we describe (Supplemental Figure S1). The increase in the number of misconceptions between initial and revised drafts can be explained by considering the origin of the additional misconceptions. Of these, some were added without any direct exposure to the misconception through 
peer review, such as presented in case C (Figure 2), in which a student adds a misconception after receiving feedback indicating that more details should be included about a concept. In only three instances was a misconception directly communicated to a student and then incorporated into the paper. There were no instances, however, in which students added a misconception from a paper they read. Thus, peer review led to the remediation of first draft misconceptions and also elicited further misconceptions, both of which can be valuable in enhancing student learning, depending on the goals an instructor has for the assignment.

Through qualitative analysis of sociograms (Figure 2), we developed six profiles to characterize how the peer-review process led to remediation and elicitation of student-held misconceptions. Half of our presented cases led to remediation of misconceptions, either through the peer-review process or through students correcting their own mistakes upon revision. The former builds on existing literature, which indicates that students can provide valid feedback to their peers (Timmerman, 2008; Lundstrom and Baker, 2009) and specifically that peer review can remediate misconceptions (Patchan et al., 2009). There were two cases leading to the addition of misconceptions, the more frequent of the two cases involved misconceptions being added to address comments asking for more details. The further elicitation of misconceptions can be useful, as it allows further opportunities for instructors to identify areas of student difficulty. We also observed instances in which students did not incorporate feedback from their peers, as presented in case F. Further investigation is required to determine what factors influence how students view peer feedback and what guides their decisions to incorporate or ignore suggestions.

\section{CONCLUSIONS}

In this work, we examined four writing assignments from an introductory biology class, and identified both misconceptions that had been previously reported in the literature and new misconceptions that have not yet, to our knowledge, been documented (Tables 1-4). Peer review and revision had two main outcomes: the remediation of misconceptions and the elucidation of further misconceptions. The first leads to the reinforcement of student knowledge through the role of expert as they correct their peers' errors and provides students who hold misconceptions an opportunity to correct their incorrect beliefs. The second serves as a tool for instructors to ensure that as many gaps in student knowledge have been identified as possible, which can then inform instruction of the relevant content.

\section{Limitations}

Analysis of student writing is only one method of investigating student misconceptions. Interviews may provide more information about the nature and origin of each misconception, because researchers can probe further during an interview. By contrast, a greater range of misconceptions may be obtained through student writing, because a larger number of student responses can be collected. The WTL assignments could also be revised to more effectively identify and address student misconceptions based on the analysis presented here. A more scaffolded peer-review process, wherein students are provided with examples of good and bad peer reviews, could potentially increase learning gains. Further analysis of peer reviews might have drawn out additional themes.

The results of this study are limited in their generalizability because 16 of the 36 participants intended to major in engineering. Owing to the small number of biology-focused students, scores and the number of misconceptions may not be representative of populations in biology courses in upperlevel courses or at other institutions. Furthermore, because this study was conducted in a classroom environment, there were several instances of students not completing both the initial and final response in one of the assignments, and thus we were unable to analyze all student writing for all assignments.

\section{Implications}

The WTL assignments presented here can be used for research and instructional purposes. Researchers wishing to investigate student knowledge pertaining to specific topics, either of misconceptions or more generally, can create WTL assignments to draw out student conceptions specifically on those topics. Researchers could also use student responses drawn from WTL assignments as distractors in concept inventories (Tamir, 1971; Treagust, 1986). Instructors can similarly use WTL assignments to direct student learning. They can also be used in combination with pre/post concept inventories, either to assess whether students have learned the desired content or, through preadministration of a concept inventory, to identify what areas of student difficulty to target with a WTL assignment.

The WTL assignments are structured to reduce the time commitment of instructors when implementing them in their courses. As this and other work shows, students are able to provide substantive feedback to their peers (Patchan et al., 2009; Zhang et al., 2017). This means that, when using WTL assignments as described here, the role of the instructor can range from just assigning points for completion of the assignment without providing any feedback to looking through a subset of the assignments or peer reviews to identify trouble spots and address them with students. Our results indicate that a cursory read-through of student initial drafts may also expose a number of student misconceptions. The peer reviews themselves are also a rich source of information for identifying areas of difficulty or specific misconceptions and are less time consuming to read than entire student drafts. Finally, by gathering this information over time, instructors can compile lists of misconceptions that they can address in their teaching or provide students with before editing their revised drafts so that the students themselves can address any misconceptions present in their own writing. The results presented herein show great promise for the use of WTL in identifying and addressing student misconceptions, in both research and instructional contexts.

\section{ACKNOWLEDGMENTS}

We thank the University of Michigan Third Century Initiative for funding. We also thank Brittany Tang and Elizabeth Horn for assisting in the identification of misconceptions in the student writing. 


\section{REFERENCES}

Abimbola, I. O. (1988). The problem of terminology in the study of student conceptions in science. Science Education, 72(2), 175-184. https://doi .org/10.1002/sce.3730720206

Abimbola, I. O., \& Baba, S. (1996). Misconceptions \& alternative conceptions in science textbooks: The role of teachers as filters. American Biology Teacher 58(1), 14-19. https://doi: 10.2307/4450067

Abraham, J. K., Perez, K. E., Downey, N., Herron, J. C., \& Meir, E. (2012). Short lesson plan associated with increased acceptance of evolutionary theory and potential change in three alternate conceptions of macroevolution in undergraduate students. CBE-Life Sciences Education, 11(2), 152164. https://doi.org/10.1187/cbe.11-08-0079

Anderson, P., Anson, C. M., Gonyea, R. M., \& Paine, C. (2015). The contributions of writing to learning and development: Results from a large-scale multiinstitutional study. Research in the Teaching of English, 50(2), 199-235.

Birenbaum, M., \& Tatsuoka, K. K. (1987). Open-ended versus multiple-choice response formats - it does make a difference for diagnostic purposes. Applied Psychological Measurement, 11(4), 385-395. https://doi .org/10.1177/014662168701100404

Bodner, G. M. (1986). Constructivism: A theory of knowledge. Journal of Chemical Education, 63(10), 873. https://doi.org/10.1021/ed063p873

Brown, D. E. (1992). Using examples and analogies to remediate misconceptions in physics: Factors influencing conceptual change. Journal of Research in Science Teaching, 29(1), 17-34. https://doi.org/10.1002/tea.3660290104

Cakir, M. (2008). Constructivist approaches to learning in science and their implications for science pedagogy: A literature review. International Journal of Environmental \& Science Education, 3(4), 193-206.

Chi, M. T. H. (2005). Commonsense conceptions of emergent processes: Why some misconceptions are robust. Journal of the Learning Sciences, 14(2), 161-199. https://doi.org/10.1207/s15327809jls1402_1

Cho, K., \& MacArthur, C. (2010). Student revision with peer and expert reviewing. Learning and Instruction, 20(4), 328-338. https://doi.org/ 10.1016/j.learninstruc.2009.08.006

Clement, J. (1993). Using bridging analogies and anchoring intuitions to deal with students' preconceptions in physics. Journal of Research in Science Teaching, 30(10), 1241-1257. https://doi.org/10.1002/tea.3660301007

Cliff, W. H. (2006). Case study analysis and the remediation of misconceptions about respiratory physiology. Advances in Physiology Education, 30(4), 215-223. https:// 10.1152/advan.00002.2006

Coll, R. K., \& Treagust, D. F. (2003). Investigation of secondary school, undergraduate, and graduate learners' mental models of ionic bonding. Journal of Research in Science Teaching, 40(5), 464-486. https://doi.org/10.1002/ tea. 10085

Duit, R. (2009). Bibiography-STCSE: Students' and teachers' conceptions and science education. Learning, 37(1985), 1-29.

Duit, R., \& Treagust, D. (2003). Conceptual change: A powerful framework for improving science teaching and learning. International Journal of Science Education, 25(6), 671-688. https://doi.org/10.1080/09500690305016

Ferguson, R. L. (2007). Constructivism and social constructivism. Theoretical frameworks for research in chemistry/science education. Upper Saddle River, NJ: Pearson Prentice Hall

Finkenstaedt-Quinn, S. A., Halim, A. S., Chambers, T. G., Moon, A., Goldman, R. S., Gere, A. R., \& Shultz, G. V. (2017). Investigation of the influence of a writing-to-learn assignment on student understanding of polymer properties. Journal of Chemical Education, 94(11), 1610-1617. acs .jchemed.7b00363. https://doi.org/10.1021/acs.jchemed.7b00363

Fry, S. W., \& Villagomez, A. (2012). Writing to learn: Benefits and limitations College Teaching, 60(4), 170-175. https://doi.org/10.1080/87567555 2012.697081

Grunspan, D. Z., Wiggins, B. L., \& Goodreau, S. M. (2014). Understanding classrooms through social network analysis: A primer for social network analysis in education research. CBE-Life Sciences Education, 13(2), 167178. https://doi.org/10.1187/cbe.13-08-0162

Haslam, F., \& Treagust, D. F. (1987). Diagnosing secondary students' misconceptions of photosynthesis and respiration in plants using a two-tier multiple choice instrument. Journal of Biological Education. 21(3), 203211. https://doi.org/10.1080/00219266.1987.9654897

Hendry, G. D. (1996). Constructivism and educational practice. Australian Journal of Education, 40(1), 19-45. https://doi.org/10.1177/000494419604000103
Kadushin, C. (2012). Understanding social networks. New York: Oxford University Press.

Karpudewan, M., Zain, A. N. M., \& Chandrasegaran, A. L. (2017a). Introduction: Misconceptions in science education: An overview. In Karpudewan, M., Zain, A. N., \& Chandrasegaran, A. L. (Eds.), Overcoming students' misconceptions in science (pp. 1-5). Singapore: Springer. https://doi .org/10.1007/978-981-10-3437-4_1

Karpudewan, M., Zain, A. N. M., \& Chandrasegaran, A. L. (Eds.) (2017b) Overcoming students' misconceptions in science. Singapore: Springer https://doi.org/10.1007/978-981-10-3437-4

Klein, P. D. (2015). Mediators and moderators in individual and collaborative writing to learn. Journal of Writing Research, 7(1), 201-214.

Klymkowsky, M. W., \& Garvin-Doxas, K. (2008). Recognizing student misconceptions through Ed's Tools and the Biology Concept Inventory. PLOS Biology, 6(1), e3. https://doi.org/10.1371/journal.pbio.0060003

Leonard, M. J., Kalinowski, S. T., \& Andrews, T. C. (2014). Misconceptions yesterday, today, and tomorrow. CBE-Life Sciences Education, 13(2), 179-186. https://doi.org/10.1187/cbe.13-12-0244

Loertscher, J., Villafañe, S. M., Lewis, J. E., \& Minderhout, V. (2014). Probing and improving student's understanding of protein $\alpha$-helix structure using targeted assessment and classroom interventions in collaboration with a faculty community of practice. Biochemistry and Molecular Biology Education, 42(3), 213-223. https://doi.org/10.1002/bmb.20787

Lundstrom, K., \& Baker, W. (2009). To give is better than to receive: The benefits of peer review to the reviewer's own writing. Journal of Second Language Writing, 18(1), 30-43. https://doi.org/10.1016/j.jslw.2008 .06 .002

Marmaroti, P., \& Galanopoulou, D. (2006). Pupils' understanding of photosynthesis: A questionnaire for the simultaneous assessment of all aspects. International Journal of Science Education, 28(4), 383-403. https://doi.org/10.1080/09500690500277805

National Research Council. (2012). Discipline-based education research: Understanding and improving learning in undergraduate science and engineering. Washington, DC: National Academies Press. https://doi. $10.17226 / 13362$

Nehm, R. H., \& Ha, M. (2011). Item feature effects in evolution assessment. Journal of Research in Science Teaching, 48(3), 237-256. https://doi org/10.1002/tea.20400

Parker, J. M., Anderson, C. W., Heidemann, M., Merrill, J., Merritt, B., Richmond, G., \& Urban-Lurain, M. (2012). Exploring undergraduates' understanding of photosynthesis using diagnostic question clusters. CBE-Life Sciences Education, 11(1), 47-57. https://doi.org/10.1187/cbe.11-07-0054

Patchan, M. M., Charney, D., \& Schunn, C. D. (2009). A validation study of students' end comments: Comparing comments by students, a writing instructor, and a content instructor. Journal of Writing Research, 1(2), 124-152. https://doi.org/10.17239/jowr-2009.01.02.2

Pelaez, N. (2003). Problem-based writing with peer review improves academic performance in physiology. Advances in Physiology Education 26(1-4), 174-184. https://doi.org/10.1152/advan.00041.2001

Posner, G. J., Strike, K. A., Hewson, P. W., \& Gertzog, W. A. (1982). Accommodation of a scientific conception: Toward a theory of conceptual change. Science Education, 66(2), 211-227. https://doi.org/10.1002/sce.3730660207

Reynolds, J. A., Thaiss, C., Katkin, W., \& Thompson, R. J. (2012). Writing-tolearn in undergraduate science education: A community-based, conceptually driven approach. CBE-Life Sciences Education, 11(1), 17-25 https://doi.org/10.1187/cbe.11-08-0064

Rivard, L. O. P. (1994). A review of writing to learn in science: Implications for practice and research. Journal of Research in Science Teaching, 31(9), 969-983. https://doi.org/10.1002/tea.3660310910

Robic, S. (2010). Mathematics, thermodynamics, and modeling to address ten common misconceptions about protein structure, folding, and stability. CBE-Life Sciences Education, 9(3), 189-195. https://doi.org/ $10.1187 / \mathrm{cbe} .10$

Russell, A. A. (2013). The evolution of calibrated peer review. In Holme, T. Cooper, M. M., \& Varma-Nelson, P. (Eds.), Trajectories of chemistry education innovation and reform. Washington DC: American Chemical Society. https://doi.org/10.1021/bk-2013-1145.ch009

Scott, J. (1991). Social network analysis: A handbook (1st ed.), Thousand Oaks, CA: SAGE. 
Shi, J., Wood, W., Martin, J., Guild, N. A., Vicens, Q., \& Knight, J. K. (2010). A diagnostic assessment for introductory molecular and cell biology. CBE-Life Sciences Education, 9(4), 453-461. https://doi.org/10.1187/ cbe.10-04-0055

Shultz, G. V., \& Gere, A. R. (2015). Writing-to-learn the nature of science in the context of the Lewis dot structure model. Journal of Chemical Education, 92(8), 1325-1329. https://doi.org/10.1021/acs.jchemed.5b00064

Smith, M. K., Wood, W. B., \& Knight, J. K. (2008). The Genetics Concept Assessment: A new concept inventory for gauging student understanding of genetics. CBE-Life Sciences Education, 7(4), 422-430. https://doi .org/10.1187/cbe.08-08-0045

Tamir, P. (1971). An alternative approach to the construction of multiple choice test items. Journal of Biological Education, 5(6), 305-307. https:// doi.org/10.1080/00219266.1971.9653728

Tekkaya, C. (2003). Remediating high school students' misconceptions concerning diffusion and osmosis through concept mapping and conceptual change text. Research in Science \& Technological Education, 21(1), 5-16. https://doi.org/10.1080/02635140308340

Timmerman, B. E. (2008). Peer review in an undergraduate biology curriculum: Effects on students' scientific reasoning, writing and attitudes.
Retrieved December 18, 2017, from https://scholarcommons.sc.edu/ biol_facpub/1/

Treagust, D. (1986). Evaluating students' misconceptions by means of diagnostic multiple choice items. Research in Science Education, 16(1), 199207. https://doi.org/10.1007/BF02356835.

Vygotsky, L. S. (1962). Thought and language. Cambridge, MA: MIT Press.

Weston, M., Haudek, K. C., Prevost, L., Urban-Lurain, M., \& Merrill, J. (2015). Examining the impact of question surface features on students' answers to constructed-response questions on photosynthesis. CBE-Life Sciences Education, 14(2), ar19. https://doi.org/10.1187/cbe.14-07-0110

Yong, C. L., \& Kee, C. Z. (2017). Utilizing concept cartoons to diagnose and remediate misconceptions related to photosynthesis among primary school students. In Karpudewan, M., Zain, A. N., \& Chandrasegaran, A. L. (Eds.), Overcoming students' misconceptions in science: Strategies and perspectives from Malaysia (pp. 9-27). Singapore: Springer. https://doi org/10.1007/978-981-10-3437-4_2

Zhang, F., Schunn, C. D., \& Baikadi, A. (2017). Charting the routes to revision: An interplay of writing goals, peer comments, and self-reflections from peer reviews. Instructional Science, 45(5), 679-707. https://doi .org/10.1007/s11251-017-9420-6 